\title{
Assessment Of Higher Order Thinking Skills (Hots) For Chemistry Pre-Service Teacher Using Computer Based Testing (CBT)
}

\author{
Luki Yunita $^{1}$, Yetti Supriyati ${ }^{2}$, Herwindo Hariwibowo ${ }^{3}$ \\ \{lukiyunita_pep16s3@mahasiswa.unj.ac.id ${ }^{1}$, yetti.supriyati@unj.ac.id ${ }^{2}$, herwindo@gmail.com ${ }^{3}$ \} \\ Department of Chemistry Education, Syarif Hidayatullah State Islamic University of Jakarta, \\ Indonesia $^{1}$ \\ Graduate Program of State University of Jakarta, Indonesia ${ }^{1,2,3}$
}

\begin{abstract}
This research is aimed to identify the ability of the chemistry pre-service teachers in undertaking the questions within the MOTS and HOTS. Furthermore, the authors involve pre-service teachers who are studying at Department of Chemistry Education Syarif Hidayatullah State Islamic University of Jakarta. What is more, the instrument of research is administrated by examining the questions' items through the CBT program consisting questions based on the learning competencies of basic chemistry in the higher education level. Therefore, the findings seem to indicate that (1) The test instrument carried the students in MOTS possesses the average $92 \%$. While, the average percentage of the students who have HOTS is about $72 \%$. Therefore, the students are able to do various kinds of questions covering HOTS;(2) The character and the preservice teachers' responses in accomplishing the questions trough CBT show the average point for about 80.1 and it is included in good category.
\end{abstract}

Keywords: Assessment, CBT, HOTS, Chemistry Pre-service Teacher

\section{Introduction}

There are some crucial factors that can help teachers and school institutions to prepare the students' competencies in developing various skills in the 21 st century, such as teachers' pedagogical ability and information technology and communication use [1]. Sudarman and Ririn stated that one of the educational problems happened is lack of the opportunities in enhancing the students' thinking skills during the learning process [2]. Furthermore, the development of technology and global information have affected the rapid enhancement of science. In fact, people can be easier to obtain various kinds of information both national and international scopes in this globalization era. Specifically, the development of science especially in chemistry higher order thinking skill enables teachers to apply technology in teaching and evaluation needs.

The importance of HOTS has influenced the development of teacher's profession in developing the problems in chemistry subject objectively without neglecting basic knowledge theory, so it can support the students to participate in HOTS[3]. It is also related to several aspects in the teaching process, such as understanding the materials, designing the materials based on the students' needs. Further on, the students as the pre-service teachers should have learning competency regarding the National Qualification of Indonesia, including HOTS that should be developed optimally. 
Importantly, HOTS is needed for chemistry pre-service teachers before having a real teaching practice in a school, especially in micro-learning which will be organized in micro class by training the basic competences of teaching in order to the pre-service teachers are able to comprehend each component comprehensively in a simple learning situation [4]. Also, micro-learning is a kind of platform for the pre-service teachers to be brave in handling the class and developing the teaching materials about chemistry in the classroom activities. Moreover, it may be developed in accordance with the chemistry education program and the curriculum used in order to fulfil the pre-service teachers' needs [5]. Relating to the learning materials, the teachers are only required to master the materials given to the students and pedagogy aspect in its development. Whereas, nowadays teachers should understand the learning materials, teaching strategies, and technology in teaching [6]. In light of the enhancement of ICT literacy, the students tend to implement technology in the classroom activities [7]. In this case, a teacher should be able to elaborate their ability to design the learning materials and pedagogy competence, learning materials with the technology, so it can create a learning process in the digital era.

In the implementation of HOTS, the learning assessment is important for the students to measure their understanding in using technology, such as computer, smartphone, tablet and other technologies, during the test. Also, the accessibility and internet connectivity can become the opportunity in implementing the information and communication technology in the classroom. Specifically, Google form is one of the software used to support teachers because of some considerations. For instances, it is easy to access, free to use, simple to operate and good enough to develop. It is included in the component of the Google Docs service. This application is appropriate for students, teachers, lecturers, office employees and professionals who like to create quizzes, forms and online surveys [8]. Furthermore, the features in the Google form, especially in the quiz, are very helpful teachers to create a test on chemistry subject that has been carried out either multiple-choice questions, entries or essays.

Therefore, the authors limit the research on micro-learning to know the students' ability in content testing of chemistry. Also, it is used to identify the students' level of the HOTS and MOTS based on 2013 curriculum and the national qualification framework of Indonesia. Moreover, the research focuses on assessing the students' ability when they use Google form in a test. Finally, this research is aimed to describe the results of students' ability that have reached HOTS and MOTS in completing computer-based test through Google form in microlearning subject.

\section{Research Methodology}

The authors administrate the research by utilizing quantitative research methodology. According to Emzir (2008), a quantitative approach is one of the research approaches that primary uses a positivistic paradigm in promoting knowledge. Also, it is intended to gain the statistic data during the research process [9]. Furthermore, the authors analyze the data through descriptive analysis by distributing questionnaire as the survey study in order to obtain the main information from the students in the Department of Chemistry Education. The questionnaires are provided to investigate the students' responses towards the use of the assessment instrument by Google form in completing the Chemistry questions' items on HOTS. In addition, the authors set 18 MOTS questions' items and 22 HOTS questions' items to be examined. What is more, the authors involve 42 chemistry pre-service teachers who are studying at Department of Chemistry Education Syarif Hidayatullah State Islamic University of Jakarta and all of them have joined micro-learning subject in academic year 2018/2019. 
Importantly, the number of the questions' items are forty multiple-choices questions with the reliability coefficient of the internal consistency 0.86 . After collecting the data, the authors carry out the analysis by calculating all of the data statistically in the quantitative form [10]. In this research, the assessment of content testing of chemistry Higher Order Thinking Skill using computer-based test will be analyzed with the percentage very good (81-100), good (6679), enough (56-65), bad (40-45), and very bad (0-39) [11].

\section{Finding and Discussion}

Based on the research findings, it seems to suggest that the multiple-choices questions that have been assessed using Computer Based Test are appropriate to be applied for the chemistry pre-service teachers as the alternative media in solving the problems during the learning evaluation [12]. Consequently, it gives a positive impact to the students' learning performances. oreover, the students should understand from the materials given and the teachers also should evaluate their teaching performances periodically. Therefore, to build a feedback between teachers and students, computer-based test can be a solution to speed up the fulfillment of the students' needs [13].

Furthermore, the use of CBT in learning process tends to increase the learning quality and learners will be easier to obtain the materials. To measure the learning objectives in teaching and learning process, the teacher carries out an assessment to know the students' difficulties in understanding the materials given [14]. What is more, the authors examine the questions' items emphasized on the HOTS (minimum in C3) to the students in the Department of Chemistry Education to know their abilities about chemistry learning materials. Higher order thinking possesses several benefits for the students, such as being more autonomous in learning, and being more credible in delivering the argument. Thus, the implementation of HOTS becomes one of the learning assessments, in which produces productive activities in the classroom [15]. Importantly, the character and the responses of pre-service teachers' in accomplishing the questions trough Computer Based Test (CBT) show the average point for about 80.1 and it is included in a good category. George (2017) confirmed that applying ICT can create teaching and learning process more effective and meaningful. Besides, it helps the teachers to develop their teaching profession through developing assignments and assessments for the students. The result of the instrument analysis based on MOTS and HOTS can be seen from Figure 1.

Fig 1. The Analysis between MOTS and HOTS in Chemistry Assessment

The test instrument carried out by the students in MOTS possesses the average $92 \%$ (very good). While, the average percentage of the students who have HOTS is about $72 \%$ (good) [16]. Therefore, the students are able to do various kinds of questions covering higher order 
thinking skills. Brookhart (2010, p. 17) argued a different perspective about the classification of thinking skills, which are LOTS or recall versus HOTS [17]. However, Anderson \& Krathwohl (2001, p.31) divided the thinking skills into middle order thinking skills and higher order thinking skill by pointing to some important aspects. For instances, understanding, applying, analyzing, evaluating, and expressing [18]. Consideration in high order can be adjusted based on the school institution and the students' characteristics. High-level thinking for the students in primary school, secondary school and high school level has different limitation [19]. Moreover, higher order thinking skill is considered from the basic chemistry level. While, the students in the elementary school and the secondary school who have understood the learning materials can be included in higher order thinking skill, but actually it is classified into low order thinking skills.

Fig 2. The Students' Competencies of Thinking Skill based on Gender

The characteristic of questions' items in higher order thinking skills between male and female indicates different result. Based on the Figure 2, the percentage of MOTS of male students reached $54 \%$ and the female students attained to $48 \%$. However, the percentage of HOTS of male achieved $46 \%$, while the female students reach up to 52\%. According to Brookhart in Shidiq, higher order thinking skills can be utilized to find out an understanding of how students 'thinking will be different and what they learn can be improved by using special assessments that uncover students' thinking. Higher Order Thinking Skills in learning are applications of thought processes for complex situations and have many variables. All students can think, but most students need encouragement and guidance for higher-order thinking processes [20]. Thinking skills distinguish how far the teacher's science uses activities that encourage students to use their higher cognitive skills so as to think. As prospective chemistry preservice teachers for teacher science and encourage them to use different teaching strategies, especially cognitive strategies needed to achieve high-level thinking skills [21].

The research conducted by other researchers shows that difficulties in generating ideas experienced by students will cause students to experience technical problems in completing their assignments. This is a major factor affecting student achievement. Therefore, students need to learn HOTS because it is an important aspect of teaching and learning, especially in higher education. Practical thinking skills are part of generic skills that must be infused in all technical subjects. Students with HOTS will easily learn, improve performance and reduce weaknesses either through conventional teaching, learning environments or individual assignment[22]. Similarly related to HOTS are high level skills which include analysis, synthesis, and evaluation as well as demanding mastery from before, such as applying routine rules for problems that are familiar or problems that are new [23]. 


\section{Conclusion and Suggestion}

\section{a. Conclusion}

Based on the results of the present research, it can be concluded that the Chemistry preservice teachers have completed the questions' items by using Google form application based on its proportion regarding the result of the research. The results seem to suggest that (1) The test instrument carried out by the students in MOTS possesses the average $92 \%$. While, the average percentage of the students who have HOTS is about $72 \%$. Therefore, the students are able to do various kinds of questions covering higher order thinking skills, (2) The character and the pre-service teachers' responses in accomplishing the questions trough Computer Based Test (CBT) show the average point for about 80.1 and it is included in good category.

\section{b. Suggestion}

The result of the present research can be utilized to support the further research focusing on the higher order thinking skills. Specifically, computer-based test may be utilized as one of the alternative instruments to assess the students' higher order thinking skills.

\section{References}

[1] Schoen, L., \&Fusarelll, L.: Innovation,NCLB, and the fear factor: The challenge of leading schools in the 21st century Educational Policy. pp. 181-203, (2008)

[2] Handayani, R.:Pengaruh Pembelajaran Problem Solving Berorientasi HOTS (Higher Order Thinking Skills). No.1, 1051-1062.Inovasi Pendidikan Kimia (2013)

[3] Zohar, A., Degani, A., \& Vaaknin, E.:Teachers' beliefs about low-achieving students and higher order thinking. 17(4), 469-485.Teaching and Teacher Education (2001)

[4] Tim UNY.:Buku panduan microteaching. Universitas Negeri Yogyakarta, Yogyakarta (2012)

[5] Izataki, Arina Fuady.: Evaluasi Kesesuaian Perkuliahan Microteaching Pendidikan Fisika Terhadap KKNI Di UIN Sunan Kalijaga Inovasi Pendidikan IPA, 1(April), 3645, Yogyakarta (2015)

[6] Colvin, J. C., \& Tomayko, M. C.: Putting TPACK on the Radar : A Visual Quantitative Model for Tracking Growth of Essential Teacher Knowledge, 15, 68-84 (2015)

[7] Gunbatar.M.S.:The Study on Developmnt of Information and Communication Technology Attitude Scale. (Journal of Kirsehir Education Faculty, 2014) 15 (1) (2014)

[8] Batubara, H. H.: Penggunaan Google Form Sebagai Alat Penilaian Kinerja Dosen di Prodi PGMI UNISKA Muhammad Arsyad Al Banjari. Jurnal Pendidikan Dasar Islam, 8(2) (2016)

[9] Emzir.: Metodologi Penelitian Pendidikan_Kuantitatif \& Kualitatif (Korelasional, Eksperimen, Ex Post Facto, Etnografi, Grounded Theory, Action Research,Rajagrafindo Persada, hlm. 28, Jakarta (2008)

[10] Sugiyono.: Statistika untuk Penelitian. Alfabeta. Hal. 29, Bandung (2011)

[11] Arikunto, S.: Prosedur Penelitian: Suatu Pendekatan Praktik. Rineka Cipta, Jakarta (2013)

[12] Novrianti.: Pengembangan Computer Based Testing ( CBT ) Sebagai Sebagai Alternatif Tes Hasil Belajar, 17(1), 34-42, (2014)

[13] John, Santrock.: Psikologi Pendidikan, Edisi Kedua, h. 638 Kencana, Jakarta (2008) 
[14] Pakpahan, R.: Model Ujian Nasional Berbasis Komputer: Manfaat Dan Tantangan Computer-Based National Exam Model: Its Benefits And Barriers, 1(April), 19-36 (2016)

[15] Tri Widodo, S. kadarwati.: Higher Order Thinking Berbasis Pemecahan Masalah untuk Meningkatkan Hasil Belajar Berorientasi Pembentukan Karakter Siswa. Februari N(Th.XXXII), 161-171. Cakrawala Pendidikan, (2013)

[16] George, A., \& George, A.: Evaluating the potential of teacher-designed technologybased tasks for meaningful learning: Identifying needs for professional development (2017)

[17] Brookhart S.M.: How to asses higher order thinking skills in your classroom (2010)

[18] Anderson, T.W. \& Krathwohl.: A taxonomy for learning, teaching, and assessing: a revision of bloom's taxonomy of educational objectives, abriged edition. Addison Wesly Longman, Inc, New York (2001).

[19] Hartini, S.: Pengembangan Higher Order Thinking Multiple Choice Test., 1(April), 86101 Jurnal Inovasi Pendidikan IPA (2015)

[20] Syahidul Shidiq, A., Masykuri, M., \& Elfi Susanti V.: Analisis Higher Order Thinking Skills (HOTS) Menggunakan Instrumen Two-Tier Multiple Choice Pada Materi Kelarutan Dan Hasil Kali Kelarutan Untuk Siswa Kelas XI SMAN 1 Surakarta. 20152159, Prosiding Seminar Nasional Pendidikan Sains, (November), Surakarta (2015).

[21] Saido, G. A. M., Siraj, S., \& Nordin, A. B. U. B.: Teaching Strategis Scale for Promoting Higher Order Thinking Skills, 91-94 Proceedings of ISER 5th International Conference, Singapore (2015)

[22] Heong, Y. M., Othman, W. B., Yunos, J. Bin, Kiong, T. T., Hassan, R. Bin, Mohaffyza, M., \& Mohamad, B.: The Level of Marzano Higher Order Thinking Skills among Technical Education Students, 1(2) (2011)

[23] Syahida, Ani dan Dedi Irwandi.: Analisis Keterampilam Berpikir Tingkat Tinggi Pada Soal Ujian Nasional Kimia. 7(1) 77-87 Journal EduSains, Jakarta (2015). 